下䅡切痕部下方にみられた濾胞性歯襄胞の 1 例

西嶋克已*・岸幹二*・駒井正昭*

前田健一郎*・和気和也*・元 井 信**

\title{
A case of impacted third molar and dentigerous cyst located below the sigmoid notch of the mandible.
}

\author{
Katsumi NishijımA* = Kanji KIsHI* ${ }^{*}$ Masaaki Komar* Kenichiro MaEdA* \\ Kazuya WAKE* . Makoto Motor**
}

\section{緒}

言

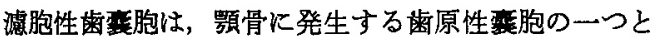
され，その報告は数多くみられる.これら露胞のらち下 顠智歯部に生じたすのは好んで下顎枝に向かって增大す る゙といわれている、しかし，本邦において下影切痕部に 発生した報告例は，われわれが涉猟した範囲ではみられ 才゙, 欧米です Traiger et al. $(1965)^{2)}$, Gehrig \& Fre-

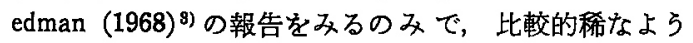
である.

今回われわれは，60歳女性で左側下顎切痕部下方にみ られた濾胞性雪衰胞を経験したので報告する。

症例

患 者: ，60歳，女性，

初 診: 昭和 47 年 3 月回.

主 訴: 左側下颚角部の有痛性属脹および開口障害.

既往歴, 家族歴 : 特記事項なし.

現病歴：約 5 力月前より左側下顎角部から耳前部にか けて有痛性腫脹および開口障害をきたし，某病院にて耳 下腺炎の疑いの診断にて化学療法をらけた。 しかし腫脹 が減退しないため本学耳算科を受診しX線撮影後, 当科 に紹介された。

現症: 体格, 栄養中等度, 血液検査で白血球の堌加 （表 1）がみられたが，その他化学検查, 血清検査等に 落変はなく，身体他部にす特記すべき所見は認められな かった.

* 岡山大学医学部口沿外科学教室（主任 : 西嶋克巳教授）

** 剛山大学医学部第 2 病理学教室 (主任 : 小川勝士教授)

*IDepartment of Oral Surgery, Okayama University

Medical School (Chief : Prof. Katsumi Nishijima)

** 2 nd Department of Pathology, Okayama University Medical School (Chief : Prof. Katsuo Ogawa)

受付 : 昭和51年 3 月22日

表 1 血液検査所見

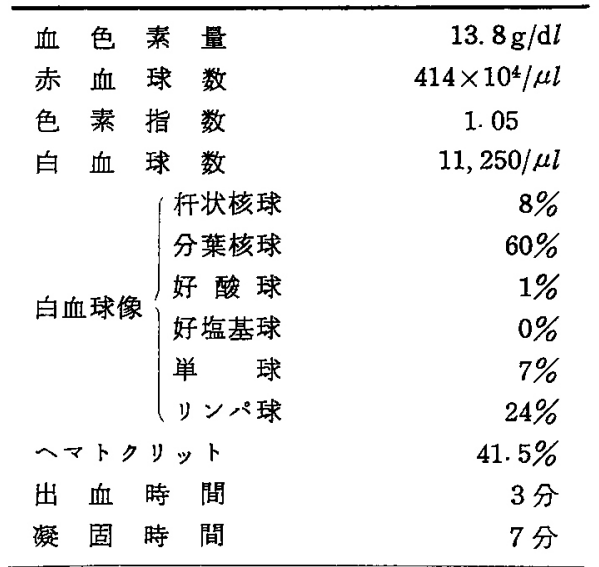

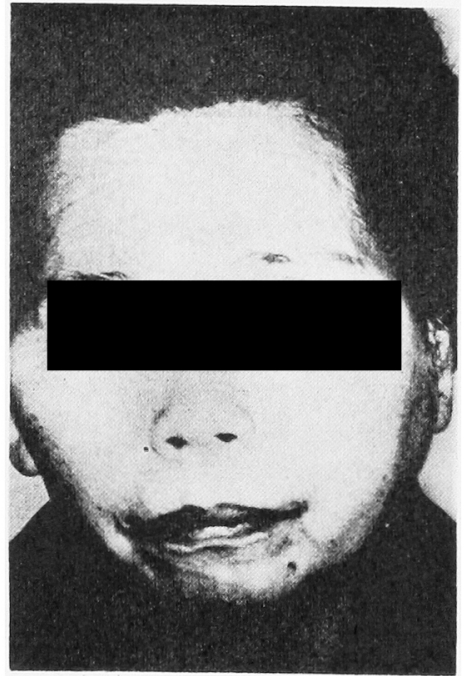

写真 1 入院時顔貌所見 


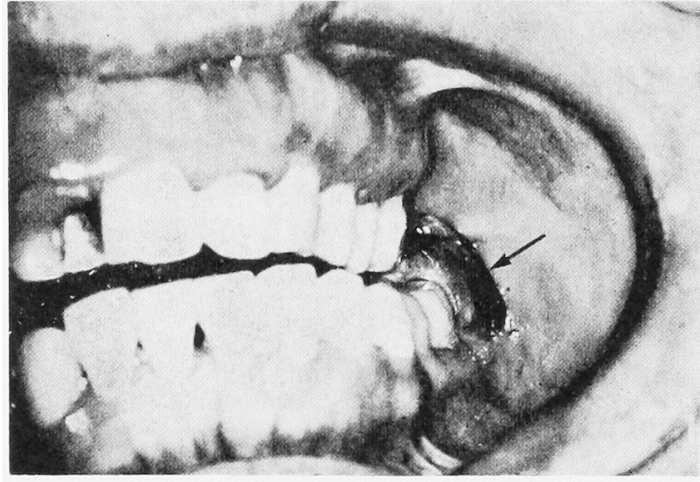

写真 2 入院時の開口状態拉よび $\overline{7}$ 部遠心煩 側の小指頭大，鵎冠状の齿肉增殖 $(\swarrow)$

顔貌所見：左側下顠角部から耳前部にかけて皮覤は発 赤し，び漫性・有痛性腫脹および硬結が著明で，顔貌は 左右非対称であったが，顎下リンパ節の腫脹，壬痛は認 められなかった（写真 1 ).

口腔内所見 : $\sqrt{7}$ 部遠心頓側に小指頭大, 鷄 冠状の歯 肉の増殖が認められ，同部より外上方に向けて瘦孔の形 成を認めた。 また開口障害は著しく， $\frac{1 \mid 1}{1 ! 1}$ 切端間で約 $2 \mathrm{~mm}$ であった（写真 2 ）。

X楾所見：根端を下顎切痕部に，歯冠を下罘枝下方に 向けた埋伏智歯がみられ，齿冠周四に拇指頭大，単胞性 で境界明瞙なX線透過像を認めた（写真3，A・B）.
臨床診断 : 濾胞性歯整胞

処置ならびに経過 :上記診断のもとに入院のうえ，炤 和 47 年 4 月日日 G-O-F 全身麻酔下で旅歯お゙よび要胞摘 出を行った.

左側下顎角部下縁より下顎枝後縁にそって約 $7 \mathrm{~cm}$ の

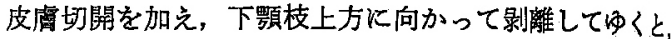
大豆大の骨吸收がみら，同部の骨を除去すると埋伏智 歯の歯冠部が現われ，さらに歯冠部を包含した裴胞壁を 認めた．埋伏智歯を抜去した後，注意深く严胞摘出を行 った、㖶胞周国の軟組織には，炎症性不良肉芽の堌殖が みられ，䜃胞部より下顠枝外側および軟組織を通じて $\mid \overline{7}$ 部遠心頓側にみられた鷄冠状の肉芽組織との交通を誌め た.したがって同肉芽様組織を切除，周囲組織の揘爬秥

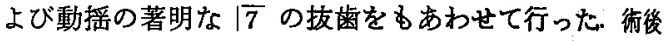
抗生物質，消炎剤の投与を行い10日目開口障害䄪 23 $\mathrm{mm}$ と軽快したため，退院した（写真4，5）.

摘出物の肉眼的所見：垔胞は淡紅色，拇指頭大で，咅 胞壁は所々で厚さ約 $3 \mathrm{~mm}$ と肥厚し，埋伏智歯蔽冠部 を包含し，黄白色不透明な内溶液を認めた。埋伏智歯の 全長は $14 \mathrm{~mm}$ ，頓舌的齿冠幅径は $10 \mathrm{~mm}$ であった

病理組織所見：亚胞壁は強い浮腫性を示し，毛細血管 の増殖，拡張がみられ，多数の好中球，形質細胞を主と する円形細胞浸潤を認めた（写真 6).

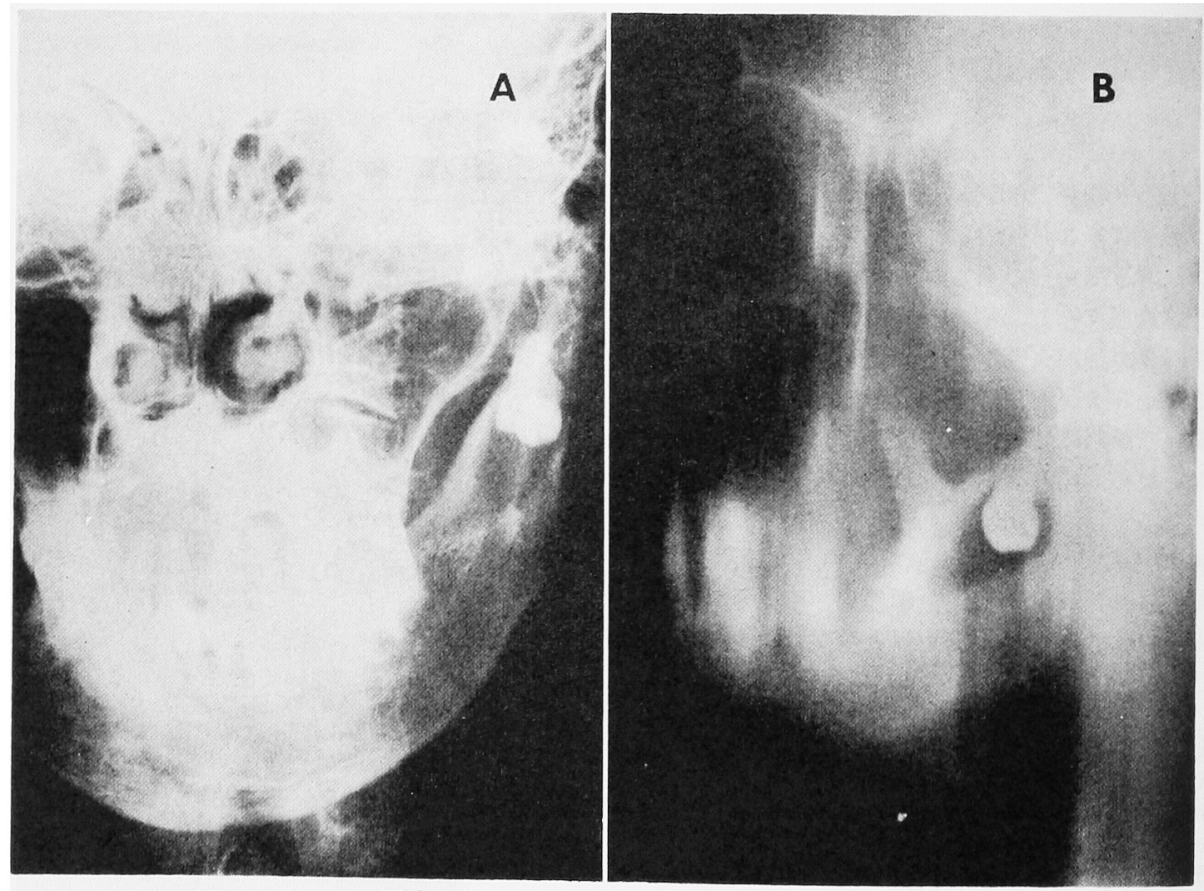

写真 $3 \mathrm{~A}$ : 頭部後前撮影

$\mathrm{B}$ : 頍部断層撮影 $(3.5 \mathrm{~cm})$ 


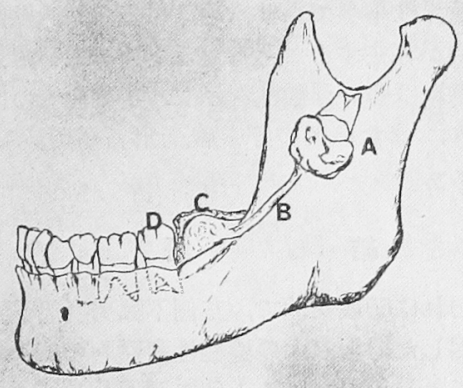

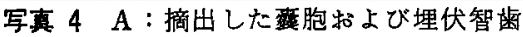
$B ：$ 襄胞部より $\overline{7}$ 部遠心煩側化 いたる瘦孔

$\mathrm{C} \cdot \sqrt{7}$ 遠心煩側歯肉部の肉芽棣 組織

D：第 2 大日歯

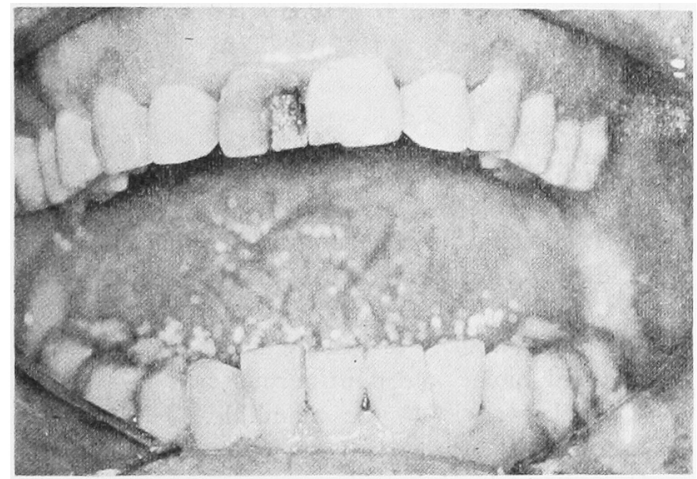

写真 5 術後 14 日目, 開口状熊

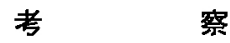

濾胞性歯震胞の発生機転については，歯牙形成中に加 わった原因による原発的発生説すなわち歯牙発育障硽説 ，また炎症その他の動機より䨑牙完成後に Malassez の 上皮細胞の增殖をきたし亯胞を形成し，歯牙の発育形成 と本症の直接的関係はないとする二次的発生説などがあ げられている。また Römer出は，埋伏歯菌胚の転位をき たすような条件，歯胚缏く压迫，外傷，乳歯の根端病

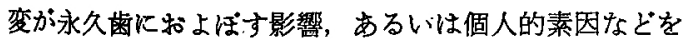
考えられる因子としてあげている．その他歯頸部穿入感 染説, 血行感染説等数多くみられるか゚，定説はみられな W.

本症のできる時期について Römer(4) は，次のように 分類している.すなわち，

1. 胎児形成期（硬組織なし）

2. 歯牙形成期（歯の形態なし）

3. 歯 冠 期 (歯の形態あり)

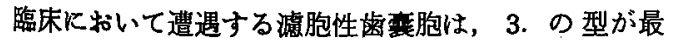

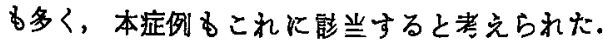

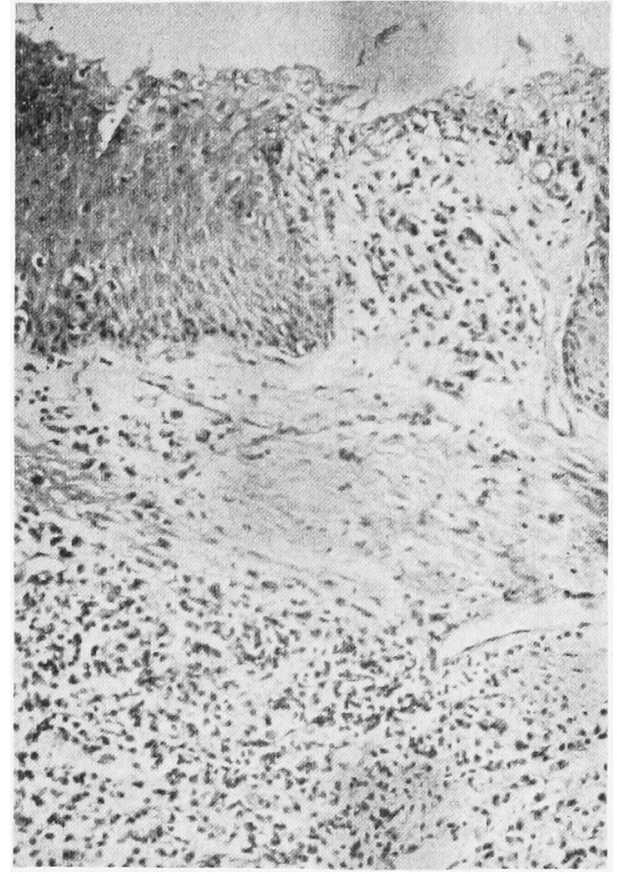

写真 6 病理組織所見 H.E. 染色

さらに Thoma $(1960)^{5}$ は,

1. Primordial cysts

2. Dentigerous cysts $\left\{\begin{array}{l}\text { Central types } \\ \text { Lateral types }\end{array}\right.$

3. Multilocular cysts

に分類している．本症例はその臨床所見，X線所見より みて, Dentigerous cyst の Central type に属するる のと考穴られた。

本症の好発年龄について, 中西ら (1962) $)^{\text {6) }} 12$ 18 藏, 藤岡 (1962) 7) 法30歳以下の若年, 特に10歳代, 氏家 $(1963)^{8)}$ は 11 20歳, 木村, 村田 (1964) ${ }^{99}$ は10 19歳, 法貴ら (1964) ${ }^{10}$ は 8〜20 歳とのべ，他の報告をる総合して 10 歳代に最も多く本症の発生を認めている.

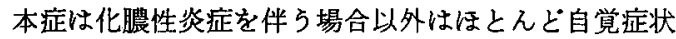
はなく, 腫脹, 疼痛, 異和感等が認められ, 始めて受診 する場合が多く，したがって早期発見は比較的困難であ る.

本症例は，60歳と高龄でかつ著明な炎症症状をきたし 受診したものであるが，霆胞の発生機転については不明 であった.

好発部位は上下顎別にみると，石井 $(1928)^{11)}$ は上影 に多く，その頻度の比は2：1であったとし，氏家要は上 顎 109 例, 下顎51例，Hammer ${ }^{12)}$ 住121例中上顎 83 例, 下 頻 38 例，石川，秋吉 ${ }^{1}$ は 155 例中上頻 88 例，下類61例を 報告し，また岡本ら (1967) ${ }^{19}$, 松井, 增田 (1968) ${ }^{14)}$ ら る上類に多かったとしている。しかし伊藤ら $(1971)^{15)}$ 


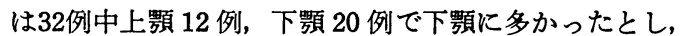
Bernick $^{16) の ~} 127$ 例では上頢102例，一嚬 115 例でほとん ど差がなかったと報告している．

歯の部位別において，石井 ${ }^{11}$ は14例中上顎前歯部過剩 歯11例に本症を報告, 石川, 秋吉 ${ }^{1)}$ は上顎では犬歯部, 切歯部が最も多く上顎全体の約70\%を占め, 智歯部がこ れにつぎ，下顎では智歯部に好発し，下䅡全体の約 $50 \%$ を占めたとのべ，さらに 155 例中25例は過剩歯に由来す るものであったと報告している．橘高ら（1958） ${ }^{17)}$ 貴島 ら $(1959)^{18)}$. 大西ら $(1960)^{19}$ ら ठ 上類では中切歯, 小 且歯, 下顎では智歯, 小臼歯の部位に多かったと述べて いる.

本邦において下顎枝に発生した本症の報告は比較的多 くみられるが(5),20) 22)，本症例のごとく下罰切痕部の直 下に埋伏智歯, 震胞を認めた症例は, われわれが渉椫し た範囲ではみられなかった。

Schwimmer et al.(1972) ${ }^{23)}$ は, 22 歳男性で左側耳前部 に外歯瘦を伴った埋伏智歯の症例を報告し，1960年より 1970年の10年間で下顎頭あるいは下類関節突起部付近の 埋伏歯報告例はわずか 4 例で，そのうち変胞を伴った症 例は 2 例2)3)であったと述べている.すなわち Traiger et al. (1965) ${ }^{2)}$ は, 47 歳女性で左側下䫫切痕部に埋伏智 歯および襄胞の発生した症例を報告し，このような例で は術後に下顎頭の骨折が起こらないように注意すること が大切であると述べている. Gehrig \& Freedman(1968) ${ }^{3)}$ は，41歳女性で左側下顎頸部に発生した埋伏智歯に由来 する滤胞性雪襄胞を報告している.この症例では, 最初 デンタル写真像で左側下顎埋伏智歯が $\mid 7$ に隣接してい た状態から，5 年後ではわずかに歯冠の一部がみえる程 度に後上方へ移動し，16年後のデンタル写真上では全く 消失し, 頭部後前像で初めて下䫇頸部にまで移動し, 表 胞を形成していたことが確認された。 また $\overline{7}$ 部遠心歯 肉に瘦孔形成がみられ，霟胞内溶液に放線菌が発見され たと報告し, 霔胞内圧の亢進により歯の位置移動は起こ り得よらが，移動に伴って骨再生がなされることは全く 稀であろうと述べている.

われわれの症例す Gehrig \& Freedman ${ }^{3)}$ の 報告と 同様の経過で，歯の位置移動，骨再生を伴い，下靧切痕 部下方に達したことも十分に考えられる.

$\mathrm{X}$ 線所見では，本症は一般に境界明瞭な透過像として みられ，含歯性表胞では変胞壁に歯冠を腔内に向けた埋 伏歯の存在がみられる場合が多く，本症例もまた典型的 な単胞性, 含歯性の型として認められた.

襄胞内溶液について, 藤岡 ${ }^{7)}$ は透明, 淡黄色, 漿液性 で，コレステリン結晶を含んでいたとしているが，本症 例においては黄白色, 透明な内溶液は認めたもののコレ ステリン結晶の有無は明確でなかった.

震胞壁の病理組織像は, 石川, 秋吉') は外層は線維性 結合組織よりなり, 内面は数層の非角化性扁平上皮で被
われ，その境界は平坦であり，ときに上皮層内に円柱上 皮, 粘液細胞が存在することもあると述べている. 本症 例では, 亯胞壁は強い浮腫性を示し, 毛細血管の増殖, 払張がみられ，また多数の好中球，形質細胞がみられ た.

\section{結語}

1）われわれは60歳女性で, 左側下顎切痕部下方の埋 伏智歯に起因した拇指頭大の濾胞性歯亯胞で, その発現 部位においてきわめて稀なる 1 例に遭遇した.

2）全身麻酔下で口腔外より埋伏智歯の拔去, 岥胞の 全摘出, あわせて瘦孔形成部の搔爬, $\overline{7}$ 抜歯を行った.

3）摘出変胞は，埋伏智歯の歯冠を包含した典型的な 単胞性, 含歯性品胞であった. 襄胞は淡紅色，拇指頭大 で, 咅胞壁は厚さ約 $3 \mathrm{~mm}$ と肥厚していた.

(本論文の要旨は昭和 47 年 10 月 7 日第 17 回日本口腔外 科学会総会に拈いて発表した.）

\section{文献}

1）石川梧朗, 秋吉正豊：口腔病理学II. 第 3 版, 永 末書店, 京都, 1969, 841頁.

2) Traiger, J. et al. : Impacted third molar and dentigerous cyst of the sigmoid notch of the mandible. OS OM OP $19: 4591965$.

3) Gehrig, J.D. \& Freedman, G. L. : Impacted third molar and dentigerous cyst of the condylar neck of the mandible. J Oral Surg $26: 6091968$.

4) Römer : 1) より引用.

5) Thoma, K. H. \& Goldman, H. M. : Oral Pathology. ed 5, Mosby Co, St Louis, 1960. p 784.

6）中西 貫，他：2 埋伏過剩歯を包含した歯患性歯 素胞の 1 例. 口科誌 $11: 4261962$.

7）藤岡幸雄 : 各種顎骨囊胞の観察，特にその成因な らびに診断に関する知見補遺. 日口外誌 $8: 247$ 1962.

8）氏家英峰：謔胞性歯牙軎胞に関する臨床的ならび に統計的研究 (抄)。口科誌 $12: 1811963$.

9）木村 潔，村田 守：臨床 2 題（イ）上顥前齿部

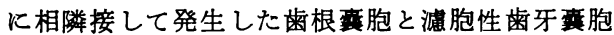
の 1 例. 日立医学会誌 4:77 1964 .

10）法貴 正，他：下顎両側犬歯を包含する沪胞性歯 軎胞の 1 例. 歯科医学 $27: 1671964$.

11) 石井 正：歯牙逆生及び原因論併せて濾胞性歯牙 亯腫の発生について。 日之歯界 101：485 1928.

12) Hammer : 1) より引用.

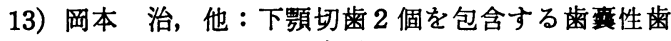
亯胞の 1 症例. 臨床歯科 $255: 191967$.

14）松井澄夫, 増田敏雄 : 汇胞性歯異胞と上下顎に数 個の埋伏歯を伴った 1 症例. 日歯評論 $308: 692$ 1968.

15）伊藤秀夫，他：多発性濾胞性歯素胞の 7 例につい て。 日口外誌 $17: 4081971$.

16) Bernick : 1) より引用. 
17）誘高一彦，他：下影左側智歯部に発生した滤胞性 歯牙暴胞の 1 例. 歯界展望 $15: 14131958$.

18）貴島 享，他：上顎正中過剩齿の埋伏に起因した 巨大な濾胞性歯牙晎胞の 1 例. 口腔科学紀要 1 : 7071959.

19）大西忠利，他：下顎右側埋伏智苗部に発生した沪 胞性歯牙亯胞 の 1 例. 歯科医学 $23: 7621960$.

20）高橋庄二郎，他：多発性溜胞性歯牙患胞の 1 例. 歯科学報 $66: 9351966$.
21）福田順子，他：姉弟の下䫇両側にみられた巨大な

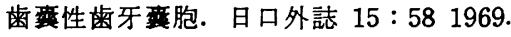

22）西嶋克巳，他：わが教室における口腔領域蛽胞性 疾患の開空術. 口科誌 $18: 5571969$.

23) Schwimmer, A. et al. : Subcondylar impaction of a third molar resulting in chronic preauricular sinus : report of case. J Oral Surg 30 : 411972. 